\title{
TESTICULAR TOXICITY PROTECTION BY MONTELUKAST AND CURCUMIN IN RATS
}

BY

\author{
Abeer I. Abd El-Fattah ${ }^{\mathrm{a} *}$, Soha S. Essawy ${ }^{\mathrm{b}}$ and Dina M. Abo-elmatty ${ }^{\mathrm{c}}$ \\ FROM
}

${ }^{a}$ Department of Biochemistry, Faculty of Pharmacy (girls), Al Azhar

University, ${ }^{\mathrm{b}}$ Department of Pharmacology, Faculty Of Medicine, Suez Canal

University, ${ }^{\mathrm{c}}$ Department of Biochemistry, Faculty Of Pharmacy, Suez Canal

University, Egypt.

\begin{abstract}
The success of etoposide for the treatment of testicular cancer is limited by its undesirable side effects on reproductive system, which is generally ascribed to inflammation and oxidative stress. In the current study, the protective effects of montelukast and curcumin on etoposide-induced reproductive toxicity were investigated. Rats were divided into four groups; group 1 was kept as control. In group 2, etoposide was administered at a dose of ( $20 \mathrm{mg} / \mathrm{kg} /$ day, i.p) for 5 days, while in groups 3; montelukast was given at a dose of $(10 \mathrm{mg} / \mathrm{kg} / \mathrm{day}$, p.o) and in group 4; curcumin was given at a dose of $(20 \mathrm{mg} / \mathrm{kg} / \mathrm{day}, \mathrm{p} .0)$ respectively for 21 days in both groups, during that i.p. injection of etoposide $(20 \mathrm{mg} / \mathrm{kg} / \mathrm{day}$, i.p) was injected from day 8 through day 12 in both groups. Etoposide induced oxidative stress via significant increase in MDA level and significant decrease in GSH level as well as SOD and CAT activities. Montelukast and curcumin prevented these effects through antioxidant properties. In addition, the deleterious effects of etoposide on spermatogenesis, serum testosterone level, oxidative stress, ATP, mtDNA and nDNA damage as well as histopathological changes were eliminated by montelukast or curcumin treatment, notably curcumin could normalized some of these parameters. The present study showed that montelukast and curcumin can reverse toxic effects of etoposide on the reproductive system that can be contributed due to anti-oxidant, antiinflammatory and antiapoptotic potential.
\end{abstract}

Keywords: Curcumin, Etoposide, Infertility, Montelukast, Oxidative damage, Spermatogenesis

\section{INTRODUCTION}

Etoposide is a semisynthetic epipodophyllotoxin agent, has a potent antineoplastic activity, usually used for treatment of small cell lung cancer, testicular cancer and lymphomas (Meresse et al., 2004; Codelia et al., 2010). Due to its undesirable inflammatory and oxidative effects on reproductive system, the therapeutic effectiveness in the treatment of testicular cancer is limited (Ortiz et al., 2009; Kanchana-Ganga et al., 2013).

It was shown that etoposide treatment induces germ cell apoptotic death and depletes seminiferous epithelium resulting in adult fertility (Stumpp et al., 2004; Kim et al., 2006). In addition, it has been demonstrated that etoposide treatment leads to a significant decrease in reproductive organ weights (Francisca et al., 2002), sperm quality (Haraguchi, 1992) and inhibition of testosterone secretion from Leydig cells as well as damages the testicular tissue (Marcon et al., 2008). However, clinical and experimental data related to the adverse effects of the etoposide treatment on 
testicular morphology are scanty and fragmentary (Francisca et al., 2002). Hence, there has been a continuous search for biological and pharmacological strategies to control etoposide-induced testicular toxicity and thus permit the administration of high quantities of the drug.

Montelukast is a selective reversible leukotriene (LT) D4 receptor antagonist. It is widely used as antiasthmatic therapy for chronic asthma and seasonal allergies with high tolerability in both children and adults (Kim et al., 2016; Teslariu et al., 2016). Recently, it attracted scientists to be evaluated as a protection for various toxic agents. It gave good results in different acute toxicities in different organs. Examples of these agents are; methotrexate in kidney (Abdel-Raheem and Khedr, 2014), dioxin and paracetamol in liver (Icer et al., 2016) and cisplatin in testes (Beytur et al., 2012). Also, up to our knowledge, there is no research regarding its protective effect on etoposide-induced toxicity. So, one of the aims of this study was to evaluate the protective mechanism of montelukast against etoposide-induced testicular toxicity.

Curcumin exhibits antioxidant property. It can significantly inhibit the generation of reactive oxygen species (ROS) both in vitro and in vivo and acts as a scavenger of free radicals (Joe et al., 2004).

Curcumin is considered to be a potent cancer chemopreventive agent and a powerful inhibitor of the proliferation of several tumor cells and it exhibits anti carcinogenic, antiviral and anti-infective properties (Tapia et al., 2012).

Experimental studies showed that administration of antioxidant compound may protect reproductive system against chemotherapeutic cytotoxicity to normal tissues which is a critical factor that undermines the curative potential of chemotherapy (Ilbey et al., 2009; Papież, 2013).

Until less toxic agents come into clinical practice, we must find new strategies to minimize the toxic effects of existing drugs. The current study was conducted to gain insights into the possibility of mechanism-based protection by montelukast and curcumin, against the reproductive toxic effects of etoposide.

\section{MATERIALS AND METHODS}

\section{Chemicals and drugs}

Etoposide (vial, $1 \mathrm{mg} / \mathrm{ml}$ ) was purchased from (MERCK, France). Montelukast and curcumin were purchased from Sigma- Chemicak2ls Comp., St Louis, MO, USA. Either montelukast or curcumin was suspended in distilled water (1 $\mathrm{gm} / 10 \mathrm{ml} \mathrm{H}{ }_{2} \mathrm{O}$ ).

\section{Animals and experimental design}

Fourty eight male Albino rats, weighing 180-200 g, were purchased from The Egyptian Organization for Biological Products and Vaccines. Rats were kept in a well-ventilated room in normal light-dark cycle and temperature $\left(25 \pm 2{ }^{\circ} \mathrm{C}\right)$. Food and water were provided ad libitum. Animals were treated in accordance with the Guidelines for Animal Experimentation (of the Ethics Review Committee) of Faculty of Pharmacy, Suez Canal University. After a 1-week acclimation period, rats were weighted and randomly assigned into four groups; 12 animals each.

Group1; rats were injected daily with saline ( $0.9 \%$ sodium chloride solution) in a volume of $(2.5 \mathrm{ml} / \mathrm{kg}$, i.p) for 15 successive days. 
Group 2; rats were injected with etoposide at a dose of (20 mg/kg/day, i.p) for five successive days (Maestroni et al., 1994).

Groups 3; rats were received montelukast (10 mg/Kg/day, p.o) (Muthuraman et al., 2010; Ozkan et al., 2010), Group v4; rats were received curcumin (20 $\mathrm{mg} / \mathrm{kg} /$ day, p.o) (Tirkey et al., 2005) respectively, for 21 days, during that i.p. injection of etoposide $(20 \mathrm{mg} / \mathrm{kg} /$ day $)$ was given from day 8 through day 12 in both groups (Maestroni et al., 1994).

At the end of the experiment, body weights were re-assessed and the percentage change of body weight (BW) was calculated using the formula (final BWinitial BW/final BW) X 100. Survival rate was observed daily.

\section{Sample collection}

Rats were then anaesthetized and sacrificed by decapitation (Vogler, 2006). Five $\mathrm{ml}$ blood samples were collected, via cardiac puncture, for serum separation, and stored at $-80^{\circ} \mathrm{C}$. Abdominal midline incision and orchiectomy was performed. After testes weighing, the right testis was stored at $-80^{\circ} \mathrm{C}$ for biochemical evaluation and the left testis was fixed in Bouin's solution for histopathologic examination. Testicular index was calculated using the formula (testicular weight/final BW) X 100.

\section{Assessment of spermatogenesis}

Serum testosterone level

Serum testosterone was determined by enzyme-linked immunosorbent assay (ELISA) kits (Ann Arbor, MI, USA) according to the manufacturer's instructions (Srivastava, 2002).

\section{Semen analysis}

\section{Sample collection}

Orchidectomy was performed. In brief; a midline incision was made and the testicles were milked out of the incision site. The testicles were exposed by incising the tunica vaginalis. The spermatic cord was exposed, ligated and incised. Three $\mathrm{ml}$ semen samples were thereafter collected and analyzed immediately (Oyeyemi and Ubiogoro, 2005).

\section{Sperm count and motility}

Neubauer chamber was used for sperm count with the help of a light microscope at 200×magnifications. In the counting chamber, five small squares for each specimen were used, the resulting number was multiplied by million to obtain the final count. One $\mathrm{ml}$ of diluted spermatozoa was also examined to calculate the number and percentage of motile sperms in 3 fields and the mean value was calculated (Pant and Srivastava, 2003).

\section{Percentage viability and morphological abnormalities}

They were determined from a total count of 300 spermatozoa in each slide. Percent viability (Live/dead ratio) was determined using 1\% Eosin and 5\% Nigrosin, dead sperms appeared red in color (Wells and Awa, 1970). The number and percentage of abnormal forms from three different fields on each sample were evaluated using a light microscope at $400 \times$ magnification (Ciftci et al., 2012) 


\section{Oxidative stress and antioxidant markers}

A part of the testis $(0.1 \mathrm{~g})$ was ice-cooled, homogenized in $1 \mathrm{ml}$ phosphate buffer ( $\mathrm{pH} 7.4$ ) and centrifuged at $3000 \times g$ for $15 \mathrm{~min}$. The supernatant was collected and kept at $-80^{\circ} \mathrm{C}$ until the analysis of reduced glutathione (GSH), catalase (CAT), superoxide dismutase (SOD) and malondialdehyde (MDA) (Ellman, 1970; Aebi, 1974; Marklund, 1992; Preuss et al., 1998) respectively, using a UV-visible spectrophotometer (UV-1601PC, Shimadzu, Japan).

\section{Inflammatory markers}

Serum C-reactive protein (CRP) was measured by ELISA kits DIA MED (Belgium) (Ben-Assayag et al., 2009). Further, one hundred $\mathrm{mg}$ testicular tissue was homogenized in $1 \mathrm{ml}$ phosphate buffer, the homogenate was centrifuged at $2000 \times g$ for 10 min and the supernatant was used for determination of TNF- $\alpha$ using ELISA kits (Biosource, USA) (Mizutani et al., 2003).

\section{Assessment of Adenosine triphosphate (ATP) content by HPLC chromatography}

Part of testicular tissue $(1 \mathrm{~g})$ was homogenized; ATP was extracted from the tissue homogenate with $10 \mathrm{ml}$ of $0.6 \mathrm{M}$ perchloric acid. The extraction mixture was centrifuged for $10 \mathrm{~min}$ at $6000 \times \mathrm{g}$, and $6 \mathrm{ml}$ of the supernatant was taken and quickly neutralized to $\mathrm{pH} 6.5$ with $1 \mathrm{M} \mathrm{KOH}$ solution. The supernatant was allowed to stand for $30 \mathrm{~min}$ in ice bath to precipitate most of the potassium perchlorate, which was removed by paper filtration. The filtrate solution was stored at $-30^{\circ} \mathrm{C}$ until analysis. The concentration of ATP was determined using the external standard methodology of Liu et al. (2006).

\section{Assessment of mitochondrial DNA integrity}

\section{Isolation of mitochondria}

One hundred mg of testicular tissue was homogenized in $0.25 \mathrm{M}$ sucrose in $0.7 \mathrm{M}$ Tris-HCl Buffer ( $\mathrm{pH}$ 7.4) and EDTA. Tissue homogenate was spun at $2500 \times \mathrm{g}$ for $10 \mathrm{~min}$. Supernatant fluid was decanted into centrifuge tubes and span at $10.000 \times \mathrm{g}$ to form primary mitochondrial pellet that is gently re-suspended in $10 \mathrm{ml}$ Tris-sucrose for washing. The pellet was re-centrifuged for several cycles and supernatant fluid was decanted. The final mitochondrial pellet was re-suspended ( $1 \mathrm{ml}$ Tris-sucrose $/ 1 \mathrm{~g}$ of original sample) (Gray and Yardley, 1975).

\section{Isolation of mitochondrial DNA (mtDNA)}

mtDNA was isolated by using isolation kit (Bio Vision, USA) (Nakahira et al., 2011).The samples were subjected to $1 \%$ agarose gel electrophoresis at $4 \mathrm{~V} / \mathrm{cm}$ using Tris-acetate with EDTA (TAE) solution as a running buffer. Furthermore, mtDNA quantity and purity were determined using Nano-Drop ${ }^{\mathrm{TM}}$ 1000Spectrophotometer V3.7 (Thermo-Fisher Scientific-Inc, Wilmington, USA).

\section{DNA laddering assay}

Genomic DNA was extracted from the testis using Wizard® Genomic DNA Purification kit (Promega Corporation, Madison, USA). DNA was then loaded onto agarose gel $(15 \mu \mathrm{g} / \mathrm{lane})$. DNA laddering was determined by constant voltage mode electrophoresis on $1.5 \%$ agarose gel containing $0.5 \mu \mathrm{g} / \mathrm{ml}$ ethidium bromide. A $1 \mathrm{~kb}$ ladder (Sigma, St. Louis, USA) served as DNA base pair marker (Sambrook et al., 2001). 


\section{Histopathologic examination}

Thin paraffin wax testicular tissue sections (4 mm thick) fixed in Bouin's solutions were stained with hematoxylin and eosin (H\&E) (Abercrombie, 1946) and examined under a light microscope X400 magnification (Olympus, BX 51, Tokyo, Japan). The number of germ cells; namely spermatogonia, pre-leptotene and pachytene spermatocytes as well as elongated spermatids was counted in at least 20 seminiferous tubules selected randomly from at least 3 cross sections/ rat. Mean tubular diameter $(\mu \mathrm{m})(15-20$ tubules/ rat) and Sertoli cells number were performed at X400 using Biovis-Image Plus Software for image analysis. This analysis was performed with the observer masked to the treatment groups.

\section{STATISTICAL ANALYSIS}

Data were expressed as mean \pm SEM and analyzed using the Statistical Package of Social Sciences (SPSS program, version 20, SPSS Inc., Chicago, IL, USA). The difference of mean values among groups was assessed by using one-way analysis of variance (ANOVA) followed by Bonferroni's multiple comparisons test. All $P$ values reported are two-tailed and $P<0.05$ was considered significant.

\section{RESULTS}

\section{Percentage change in $B W$, testicular index and survival rate}

Etoposide resulted in a significant decrease in percentage change of BW (-6.91 \pm $1.66 \%)$ versus $(14.60 \pm 1.58 \%)$ in control group $(P<0.05$, Table 1). Oral administration of montelukast $(10 \mathrm{mg} / \mathrm{Kg})$ or curcumin $(20 \mathrm{mg} / \mathrm{kg})$ resulted in a significant increase in percentage change of BW versus etoposide $(P<0.05)$.

Testicular index in etoposide-treated rats was significantly decreased $(0.39 \pm$ $0.01 \%)$ versus controls $(0.68 \pm 0.05 \%)(P<0.05$, Table 1$)$. Testicular index in montelukast and curcumin-treated groups, were preserved versus etoposide group $(P$ $<0.05$, Table 1).

Control groups showed $100 \%$ survival rate, whereas, etoposide group showed a significant lower survival rate $(66.66 \%)$. Oral administration of montelukast and curcumin significantly increased the survival rate to ( 75 and $83.33 \%$ respectively) $(P<0.05$, Table 1). Notably, curcumin induced a significant increase in body weight compared to montelukast.

\section{Testosterone level and semen analysis}

Serum testosterone was significantly deceased to $(0.96 \pm 0.07 \mathrm{ng} / \mathrm{ml})$ after etoposide treatment compared to control group $(3.60 \pm 0.38)(P<0.05$, Table 2$)$. Oral administration of either montelukast or curcumin elevated this level significantly compared to etoposide group $(P<0.05)$. On the other hand, the results of the current study indicated significant impairment of spermatogenesis upon treatment with etoposide as manifested by significant decrease in sperm count $\left(1.21 \pm 0.14 \times 10^{6} / \mathrm{ml}\right.$ vs. $\left.2.60 \pm 0.25 \times 10^{6} / \mathrm{ml}\right)$, sperm motility $\%$ (56.66 \pm 4.80 vs. $\left.89.78 \pm 5.66\right)$, viability $\%$ (61.54 \pm 4.71 vs. $86.21 \pm 6.50)$ and abnormal forms $\%(42.15 \pm 3.25$ vs. $17.11 \pm$ 1.33) as compared to control group $(P<0.05$, Table 2$)$. While, there was insignificant change in abnormal sperm forms upon administration of montelukast, it can significantly increase sperm count, motility $\%$ and viability \% compared to etoposide $(P<0.05)$. On the other hand, sperm count $(1.98 \pm 0.01)$, motility \% $(72.44 \pm 7.11)$ and viability $\%(73.68 \pm 6.61)$ were significantly increased after treatment with 
curcumin compared to etoposide group $(P<0.05)$. Notably curcumin could normalize abnormal sperm forms.

Table (1): Effect of montelukast and curcumin on percentage change of body weight, testicular index and survival rate in experimental groups.

\begin{tabular}{lllc}
\hline Groups & $\begin{array}{l}\text { Percentage change } \\
\text { of body weight }(\%)\end{array}$ & $\begin{array}{l}\text { Testicular } \\
\text { index }\end{array}$ & Survival rate (\%) \\
\hline Control & $14.60 \pm 1.58$ & $0.68 \pm 0.05$ & 100 \\
Etoposide & $-6.91 \pm 1.66^{\mathrm{a}}$ & $0.39 \pm 0.01^{\mathrm{a}}$ & $66.66^{\mathrm{a}}$ \\
$\begin{array}{l}\text { Etoposide }+ \\
\text { Montelukast }\end{array}$ & $5.71 \pm 0.96^{\mathrm{a}, \mathrm{b}}$ & $0.51 \pm 0.02^{\mathrm{a}, \mathrm{b}}$ & $75^{\mathrm{b}}$ \\
$\begin{array}{l}\text { Etoposide }+ \\
\text { Curcumin }\end{array}$ & $9.12 \pm 1.07^{\mathrm{a}, \mathrm{b}, \mathrm{c}}$ & $0.48 \pm 0.01^{\mathrm{a}, \mathrm{b}}$ & $83.33^{\mathrm{a}, \mathrm{b}}$ \\
\hline
\end{tabular}

Data was expressed as mean \pm SEM and analyzed using one-way ANOVA followed by Bonferroni's post hoc test.

${ }^{a} P<0.05$ versus control group.

${ }^{\mathrm{b}} P<0.05$ versus etoposide group.

${ }^{\mathrm{c}} P<0.05$ versus montelukast group.

Table (2): Effect of montelukast and curcumin on serum testosterone and semen analysis [sperm count, motility and abnormal forms] in experimental groups.

\begin{tabular}{cccccc}
\hline & \multirow{2}{*}{$\begin{array}{c}\text { Serum } \\
\text { testosterone } \\
(\mathbf{n g} / \mathbf{m l})\end{array}$} & $\begin{array}{c}\text { Sperm count } \\
\mathbf{1 0} / \mathbf{m l})\end{array}$ & Motility $(\boldsymbol{\%})$ & $\begin{array}{c}\text { Viability } \\
(\%)\end{array}$ & $\begin{array}{c}\text { Abnormal } \\
\text { forms }(\%)\end{array}$ \\
\cline { 3 - 6 } & $3.6 \pm 0.38$ & $2.6 \pm 0.25$ & $89.78 \pm 5.66$ & $86.21 \pm 6.50$ & $17.11 \pm 1.33$ \\
\hline Control & $0.96 \pm 0.07^{\mathrm{a}}$ & $1.2 \pm 0.14^{\mathrm{a}}$ & $56.66 \pm 4.8^{\mathrm{a}}$ & $61.54 \pm 4.71^{\mathrm{a}}$ & $42.15 \pm 3.25^{\mathrm{a}}$ \\
\hline Etoposide & $2.1 \pm 0.11^{\mathrm{a}, \mathrm{b}}$ & $2.1 \pm 0.13^{\mathrm{a}, \mathrm{b}}$ & $73.33 \pm 6.12^{\mathrm{a}, \mathrm{b}}$ & $71.22 \pm 5.32^{\mathrm{a}, \mathrm{b}}$ & $35.5 \pm 3.7^{\mathrm{a}}$ \\
\hline $\begin{array}{c}\text { Etoposide }+ \\
\text { Montelukast }\end{array}$ & $2.3 \pm 1.07^{\mathrm{a}, \mathrm{b}}$ & $1.98 \pm 0.01^{\mathrm{a}, \mathrm{b}}$ & $72.44 \pm 7.11^{\mathrm{a}, \mathrm{b}}$ & $73.68 \pm 6.61^{\mathrm{a}, \mathrm{b}}$ & $25.33 \pm 2.24^{\mathrm{b}, \mathrm{c}}$ \\
\hline $\begin{array}{c}\text { Etoposide }+ \\
\text { Curcumin }\end{array}$ & & & & & \\
\hline
\end{tabular}

Data was expressed as mean \pm SEM and analyzed using one-way ANOVA followed by Bonferroni's post hoc test.

${ }^{a} P<0.05$ versus control group.

${ }^{\mathrm{b}} P<0.05$ versus etoposide group.

${ }^{\mathrm{c}} P<0.05$ versus montelukast group

Biochemical analysis

\section{Lipid Peroxidation and antioxidant effects}

The results of the current study indicated that the testicular level of MDA was significantly $(P<0.05)$ increased (about 6.7 fold) in rat treated with etoposide. 
However, this elevation was significantly suppressed (by about 3 fold) when montelukast and curcumin were administered with etoposide $(P<0.05$, Table 3).

The current study demonstrated that testicular tissue of rats showed significant $(P<0.05$, Table 3) reduction of GSH content $(4.80 \pm 0.42)$ as well as SOD and CAT activity (44.00 \pm 3.40 and $0.47 \pm 0.06$ respectively) after etoposide treatment as compared to control group. Oral administration of montelukast and curcumin increased the testicular levels of GSH content and SOD activity significantly, besides a significant decrease in testicular level of MDA $(P<0.05)$ compared to etoposide group. Additionally, curcumin treatment had a prominent protective effect in improving the testicular levels of GSH as well as CAT activities when compared to montelukast treated group $(P<0.05$, Table 3).

Table (3): Effect of montelukast and curcumin on testicular MDA and antioxidant markers in experimental groups.

\begin{tabular}{lcccc}
\hline \multicolumn{1}{c}{ Groups } & $\begin{array}{c}\text { MDA } \\
(\mathrm{nmol} / \mathrm{mg} \\
\text { protein) }\end{array}$ & $\begin{array}{c}\text { GSH } \\
(\mathrm{nmol} / \mathrm{mg} \\
\text { protein) }\end{array}$ & $\begin{array}{c}\text { SOD activity } \\
(\mathrm{U} / \mathrm{mg} \\
\text { protein })\end{array}$ & $\begin{array}{c}\text { CAT activity } \\
\text { (U/ mg } \\
\text { protein) }\end{array}$ \\
\hline Control & $26.00 \pm 2.21$ & $24.00 \pm 1.32$ & $86.00 \pm 5.81$ & $2.36 \pm 0.17$ \\
Etoposide & $177.00 \pm 6.16^{\mathrm{a}}$ & $4.80 \pm 0.42^{\mathrm{a}}$ & $44.00 \pm 3.40^{\mathrm{a}}$ & $0.47 \pm 0.06^{\mathrm{a}}$ \\
Etoposide + Montelukast & $50.00 \pm 2.60^{\mathrm{a}, \mathrm{b}}$ & $14.60 \pm 1.27^{\mathrm{a}, \mathrm{b}}$ & $70.00 \pm 2.11^{\mathrm{a}, \mathrm{b}}$ & $0.92 \pm 0.15^{\mathrm{a}}$ \\
Etoposide + Curcumin & $53.00 \pm 5.16^{\mathrm{a}, \mathrm{b}}$ & $22.30 \pm 1.17^{\mathrm{b}, \mathrm{c}}$ & $76.00 \pm 3.06^{\mathrm{b}}$ & $2.06 \pm 0.15^{\mathrm{b}, \mathrm{c}}$ \\
\hline
\end{tabular}

Data was expressed as mean \pm SEM and analyzed using one-way ANOVA followed by Bonferroni's post-hoc test. MDA: Malondialdhyde, GSH: reduced glutathione, SOD: superoxide dismutase, CAT: Catalase.

${ }^{\mathrm{a}} P<0.05$ compared to control group.

${ }^{\mathrm{b}} P<0.05$ compared to etoposide group.

${ }^{\mathrm{c}} P<0.05$ compared to montelukast group.

The current data revealed that serum level of CRP and testicular level of TNF$\alpha$ were significantly increased respectively in etoposide-treated rats when compared to control. Oral administration of montelukast and curcumin showed anti-inflammatory activity, as manifested by a significant decrease in serum CRP and testicular TNF- $\alpha$ levels compared with etoposide-treated rats $(P<0.05$, Figure. 1\&2). Notably, the beneficial effect of curcumin on testicular level of TNF- $\alpha$ was significantly better compared to montelukast $(P<0.05$, Figure. 2$)$. 


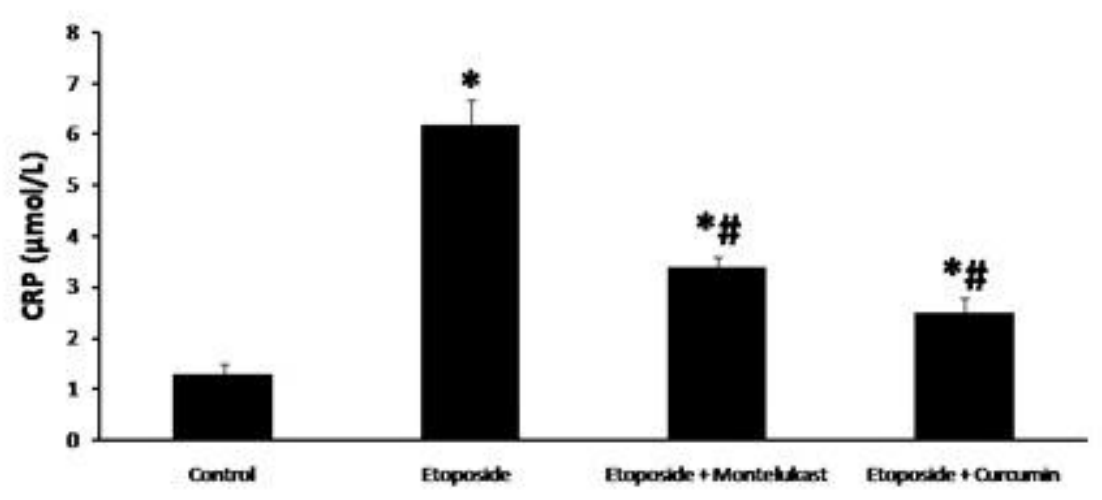

Figure (1): Serum CRP in experimental groups.

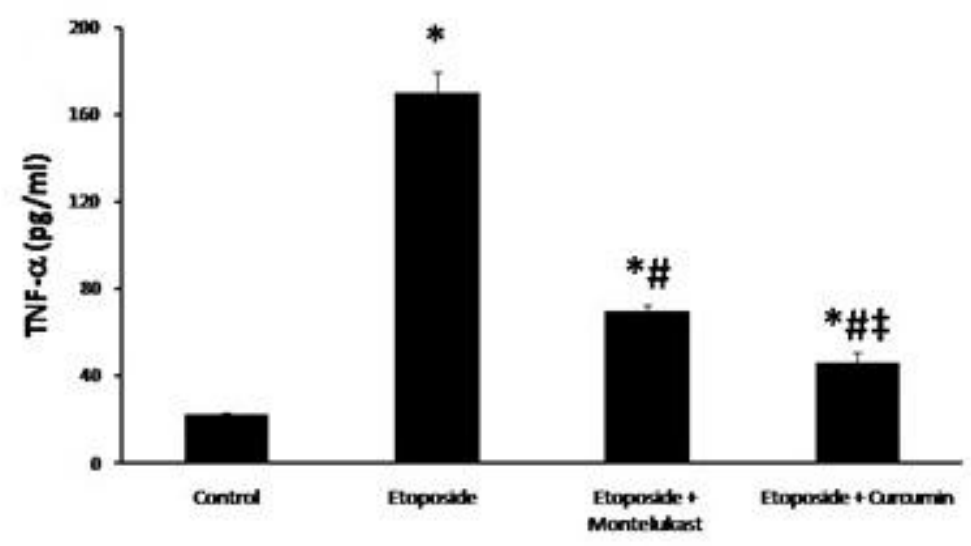

Figure (2): Testicular TNF- $\alpha$ in experimental groups.

Either montelukast or curcumin ameliorated the increased levels of CRP and TNF$\boldsymbol{\alpha}$ in etoposide-treated rats at the end of treatment period. CRP: C-reactive protein, TNF- $\boldsymbol{\alpha}$ : tumor necrosis factor- $\boldsymbol{\alpha}$. Data was expressed as mean \pm SEM and analyzed using one-way ANOVA followed by Bonferroni's post-hoc test. ${ }^{*} P<0.05$ compared to control group, ${ }^{\#} P<0.05$ compared to etoposide group, ${ }^{\ddagger} P<0.05$ compared to montelukast group.

ATP concentration in different study groups was shown in (Figure. 3 a-b). Etoposide-treated rats showed a significant decrease in ATP level $(4.55 \pm 0.38)$ compared to control group $(15.60 \pm 1.05)$. Treatment with montelukast or curcumin increased this parameter significantly compared to etoposide group $(9.95 \pm 1.55$ and $13.11 \pm 1.67$ respectively). ATP level was less reduced significantly by etoposide after curcumin administration $(P<0.05$, Figure. 3a-b). 

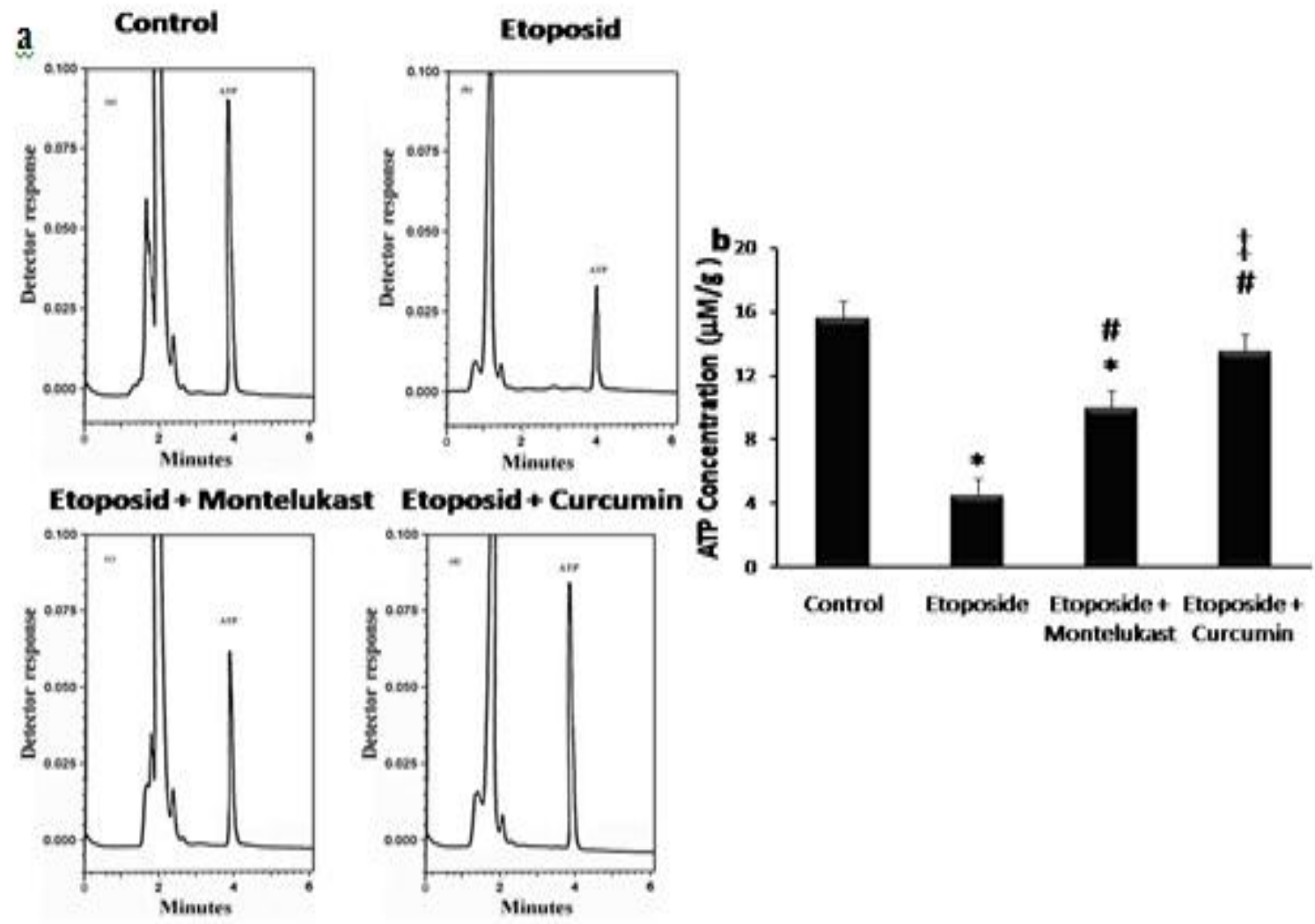

Figure (3): (a) HPLC chromatograms of ATP level in the testis of experimental groups.

\section{(b) ATP concentration in testicular tissues of experimental groups.}

Etoposide induced a significant decrease in ATP concentration compared to control group. The etoposide-induced ATP decline was significantly increased upon administration of montelukast or curcumin. Data was expressed as mean \pm SEM and analyzed using one-way ANOVA followed by Bonferroni's post-hoc test. ${ }^{*} P<0.05$ compared to control group, ${ }^{\#} P<0.05$ compared to etoposide group, ${ }^{\dagger} \mathrm{P}<0.05$ compared to montelukast group.

\section{Mitochondrial DNA (mtDNA) integrity and quantity}

In normal control animals, intact form of mitochondrial DNA was electrophoresed as a major band of approximately $16.5 \mathrm{~kb}$ (lanes 1-4, Figure. 4a). On the other hand, etoposide markedly decreased the amounts of intact mtDNA in the testicular tissue (lane 5). However, mtDNA obtained from animals treated with etoposoide and montelukast (lane 6), or curcumin (lane 7) was electrophoresed in its intact form. This suggested that all the former treatments markedly alleviated etoposide-induced injury of mtDNA.

\section{Fragmentation of $n D N A$}

The electrogram generated from gel electrophoresis shows that nDNA isolated from normal rats (lanes 1- 4, Figure. 4b), showed total ladder and smear negativity, 
whereas, etoposide exposure resulted in a marked decrease in the amount of intact nDNA in testicular tissues. Moreover, a dramatic oligonucleosome-length degradation of DNA was observed, characterized by mixed smearing and laddering (lane 5 and lane 6 Figure. $4 \mathbf{b}$ ). In contrast, Figure. $4 \mathbf{b}$ showed that no appreciable fragmentation of nDNA was found to occur in animals protected with montelukast (lanes7, 8) and curcumin (lanes 9, 10). These results demonstrated that the current treatments abolished the ladder pattern of nDNA cleavage in testicular tissue; therefore, they apparently provided protection against etoposide-induced testicular damage.

Figure $4 \mathbf{c}$ depicted the intergroup alterations in mtDNA concentration in the testicular tissues of etoposide-treated rats. In etoposide-treated group, a significant decline was observed in the testicular content of mtDNA, as compared to that of control group $(25.10 \pm 0.74$ vs. $117.30 \pm 3.58, P<0.05$, Figure. $4 c)$. The etoposideinduced mtDNA damage was significantly decreased upon administration of montelukast or curcumin. However, normalization of the mtDNA content was observed markedly upon supplementation of curcumin $(103.80 \pm 5.23)$ when compared to both etoposide treated group and montelukast treated group. Hence, the current data emphasized that etoposide-induced mtDNA damage was significantly decreased upon administration of the current treatments, especially curcumin, suggesting a possible protective potential.

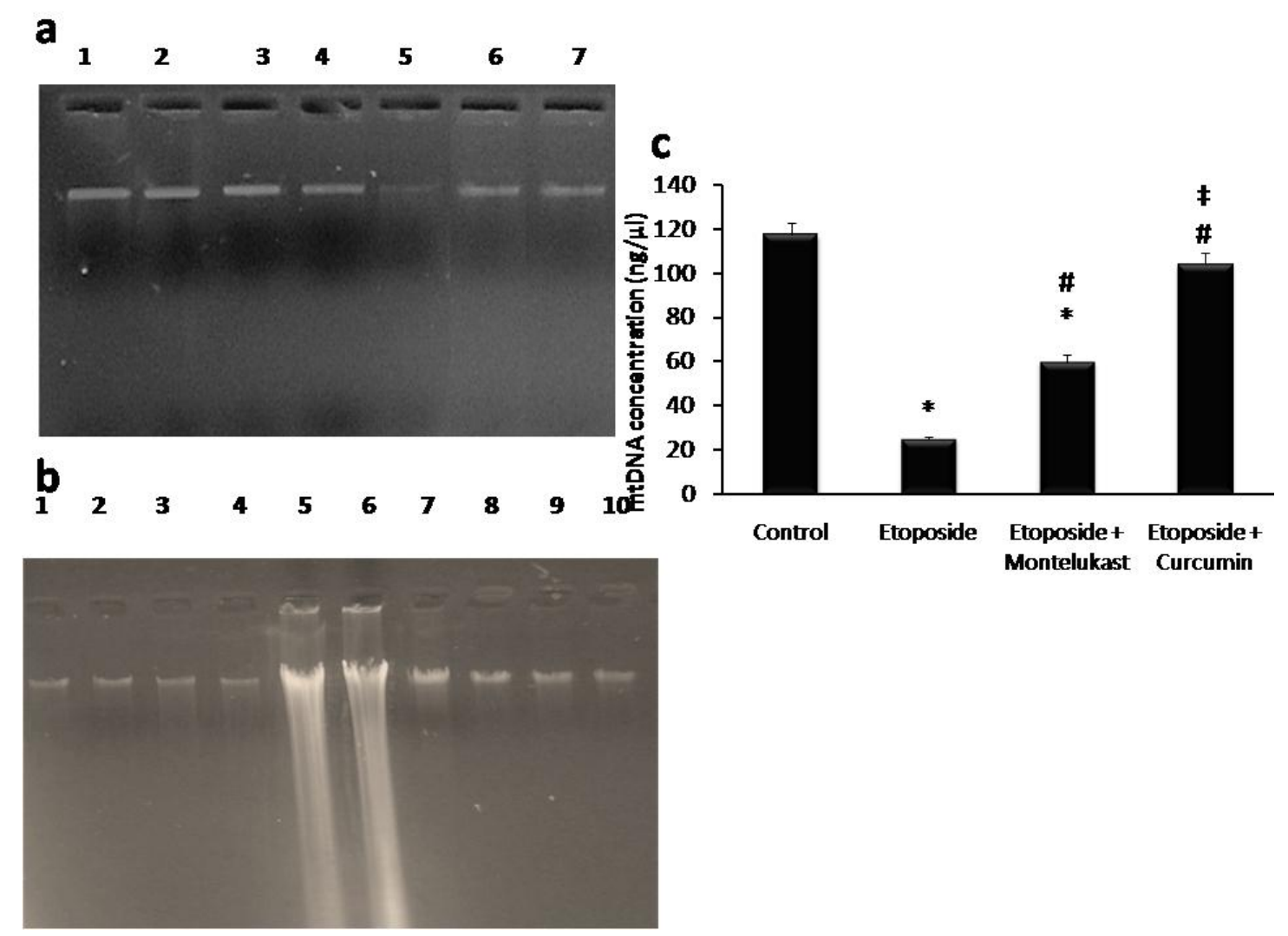

Figure (4): Mitochondrial and nuclear DNA in testicular tissue of experimental groups.

(a) Mitochondrial DNA (mtDNA) damage. Lane 1- 4, intact mtDNA isolated from normal control animal; Lane 5, mtDNA sample from the etoposoide treated 
animals; lane 6 and lane 7 show mtDNA samples isolated from animals treated with montelukast and curcumin, respectively.

(b) Nuclear DNA (nDNA) integrity. lane 1-4, intact nDNA of normal control animals; lanes 5 and 6 , nDNA samples of etoposoide-treated animals, lanes 7 and 8 nDNA samples of etoposoide + montelukast-treated animals, lanes 9 and 10, nDNA isolated from rats received curcumin + etoposoide.

(c) Mitochondrial DNA (mtDNA) concentration in testicular tissues of experimental groups. Etoposide induced a significant mtDNA damage compared to control group. The etoposide-induced mtDNA damage was significantly decreased upon administration of montelukast or curcumin. Data was expressed as mean \pm SEM and analyzed using one-way ANOVA followed by Bonferroni's post-hoc test. ${ }^{*} P<$ 0.05 compared to control group, ${ }^{\#} P<0.05$ compared to etoposide group, ${ }^{*} \mathrm{P}<0.05$ compared to montelukast group.

In table 4, insignificant change in Sertoli cell number was detected compared to controls. The Testicular tubular diameter was significantly decreased $(371.96 \pm 12.17 \mu \mathrm{m})$ Vs $(500.50 \pm 9.81)$ in controls $(P<0.05)$. Etoposide also decreased germ cells number compared to controls; spermatogonia $(1.05 \pm 0.11$ vs. $2.42 \pm 0.19)$; non-pachytene spermatocytes $(4.72 \pm 0.31$ vs. $9.34 \pm 0.67)$, pachytene spermatocytes $(3.51 \pm 0.23$ vs. $8.11 \pm 0.54)$ and spermatids $(10.87 \pm 0.75$ vs. $30.28 \pm 2.55)(P<0.05$, Table 4).

Comparing with etoposide group, the diameters of tubules in montelukast or curcumin groups were significantly increased to $(425.12 \pm 11.11 \mu \mathrm{m}$ and $420.30 \pm$ $13.07 \mu \mathrm{m}$, respectively). Number of Sertoli cells however, didn't change significantly among treatment groups.

Spermatogenesis was significantly preserved in the rats treated with montelukast or curcumin. Montelukast and curcumin increased number of spermatogonia, pachytene spermatocytes and elongated spermatids significantly $(P<$ 0.05 , Table 4) versus etoposide-treated rats. Notably, curcumin normalized the number of pachytene spermatocytes.

Table (4): Effect of montelukast and curcumin on the testicular germ cells population and seminiferous tubular diameter in experimental groups.

\begin{tabular}{ccccccc}
\hline & \multirow{2}{*}{$\begin{array}{c}\text { Tubular } \\
\text { diameter }\end{array}$} & Sertoli cells/ & \multicolumn{3}{c}{ Germ cells number / seminiferous tubule } \\
\cline { 5 - 7 } & $(\boldsymbol{\mu m})$ & tubule & Spermatogonia & $\begin{array}{c}\text { Non-pacytene } \\
\text { spermatocytes }\end{array}$ & $\begin{array}{c}\text { Pachytene } \\
\text { spermatocytes }\end{array}$ & $\begin{array}{c}\text { Elongated } \\
\text { spermatids }\end{array}$ \\
\hline Control & $500.50 \pm 9.81$ & $4.1 \pm 0.0 .01$ & $2.42 \pm 0.19$ & $9.34 \pm 0.67$ & $8.11 \pm 0.54$ & $30.28 \pm 2.55$ \\
\hline Etoposide & $371.96 \pm 12.17^{\mathrm{a}}$ & $3.77 \pm 0.02$ & $1.05 \pm 0.11^{\mathrm{a}}$ & $4.72 \pm 0.31^{\mathrm{a}}$ & $3.51 \pm 0.23^{\mathrm{a}}$ & $10.87 \pm 0.75^{\mathrm{a}}$ \\
\hline $\begin{array}{c}\text { Etoposide }+ \\
\text { Montelukast }\end{array}$ & $425.1 \pm 11.11^{\mathrm{b}}$ & $3.55 \pm 0.01$ & $1.99 \pm 0.14^{\mathrm{a}, \mathrm{b}}$ & $5.66 \pm 0.48^{\mathrm{a}}$ & $5.89 \pm 0.38^{\mathrm{a}, \mathrm{b}}$ & $18.17 \pm 0.34^{\mathrm{a}, \mathrm{b}}$ \\
\hline $\begin{array}{l}\text { Etoposide }+ \\
\text { Curcumin }\end{array}$ & $420.3 \pm 13.07^{\mathrm{b}}$ & $3.71 \pm 0.01$ & $1.88 \pm 0.08^{\mathrm{a}, \mathrm{b}}$ & $6.98 \pm 0.16^{\mathrm{a}, \mathrm{b}}$ & $7.68 \pm 0.61^{\mathrm{b}}$ & $22.33 \pm 1.24^{\mathrm{a}, \mathrm{b}}$ \\
\hline
\end{tabular}

Data was expressed as mean \pm SEM and analyzed using one-way ANOVA followed

by Bonferroni's post hoc test.

${ }^{a} P<0.05$ versus control group.

${ }^{\mathrm{b}} P<0.05$ versus etoposide group. 


\section{Histopathological results}

Control animals exhibited normal testicular morphology in the form of tightly coiled seminiferous tubules which constitute most of the testes proper. The tubular structure, diameter and germinal cells number were normal. The center of the tubules shows multiple spermatozoa. The Sertoli and Leydig cells also showed normal morphology (Figure. 5 a-c).

In testes of etoposide-treated rats, degenerative changes in the seminiferous epithelium were characterized by the giant cell formation, cytoplasmic vacuolization, pyknotic nuclei of some germinal cells, depletion and desquamation of germ cells in tubular lumen as well as absence of spermatids and spermatozoa. In addition, a various degree edema was seen in the interstitial spaces (Figure. 5d). Testicular sections observed in montelukast and curcumin treated groups showed normal interstitial tissue, little exfoliation with increased number of germinal epithelial cells within the lumen (Figure. 5 e, f) respectively.
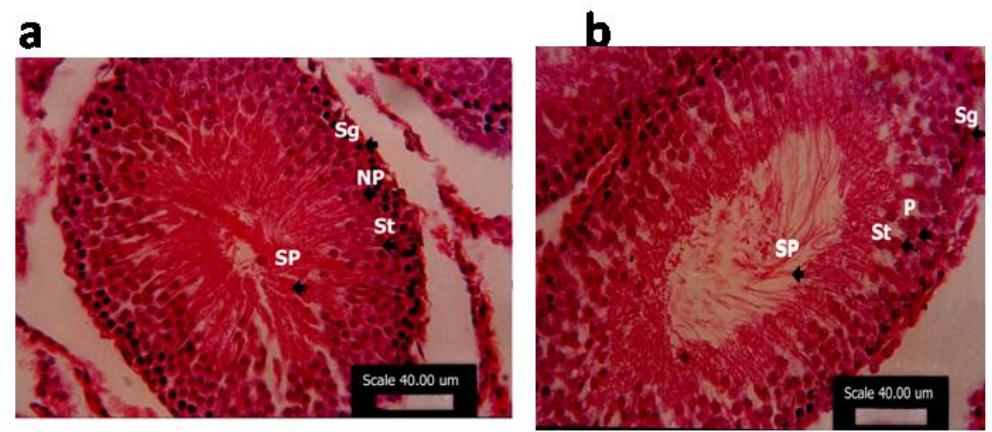

C
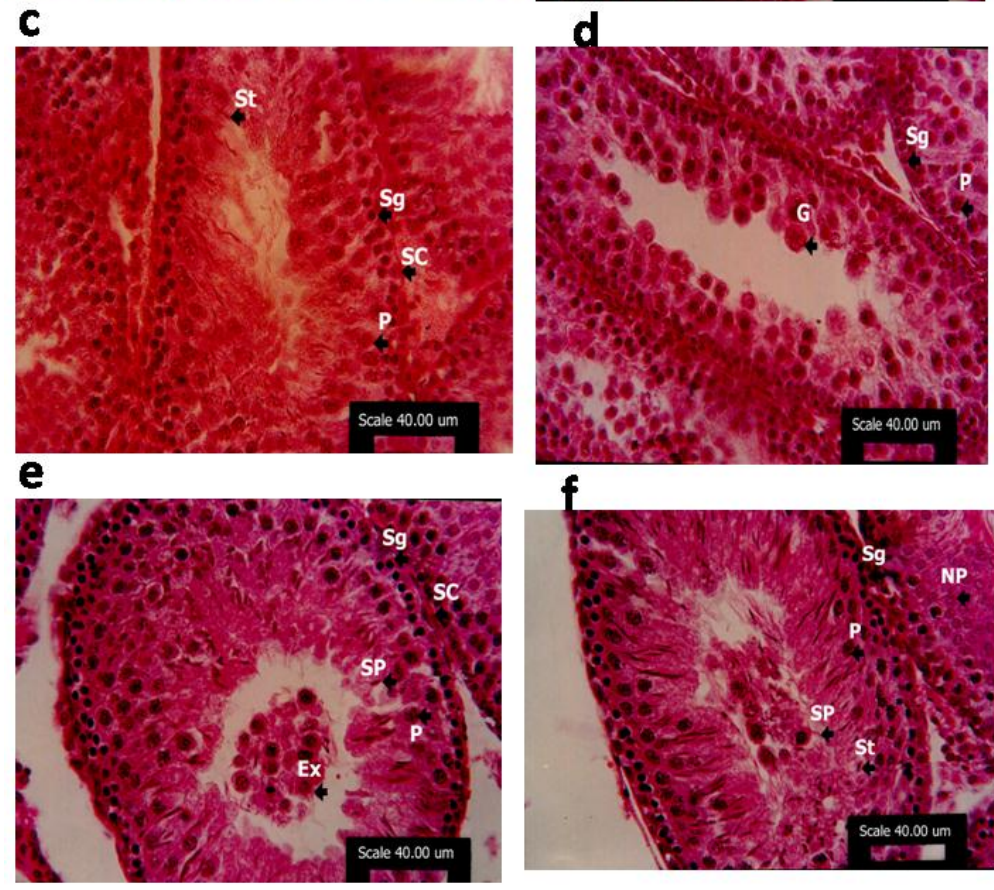

Figure (5): Testicular sections in rats of the experimental groups.

a. Testicular section of control rat showing a seminiferous tubule lined by spermatogenic cells. The center of the tubule was showing multiple spermatids and spermatozoa. b. Testicular section of normal rat, was showing parts of two seminiferous tubules separated by normal interstitial tissue with Leydig cells. c. Testicular section of normal rat, was showing also multiple normal sertoli cells and 
normal interstitial tissue. Many pachytene spermatocytes, spermatids and spermatozoa were also detected. d. Etoposide resulted in decrease in the number of primary spermatocytes and absence of spermatids and spermatozoa in seminiferous tubules. Multiple giant cells and exfoliation of germinal epithelium was also detected. e. Administration of montelukast to etoposide-treated rats induced regeneration of seminiferous tubules and increased number of germinal epithelial cells with many spermatozoa in the lumen. Some exfoliated germinal epithelial cells were still seen in the lumen. f. Testicular section of rat received curcumin and etoposide was showing normal interstitial tissue between seminiferous tubules. Little exfoliation was seen in the lumen. Many spermatids and spermatozoa were detected in the lumen. Ex: Exfoliated germinal epithelium, G: Giant cells; L: Leydig cells; NP: non- pachytene spermatocytes; P: pachytene spermatocytes; SC: Sertoli cells; Sg: Spermatogonia, St: Spermatids, S: Spermatozoa; Hematoxylin and eosin X 400, Scale bar $40.00 \mu \mathrm{m}$.

\section{DISCUSSION}

Etoposide has anticancer properties by generating breaks in cellular DNA but its therapeutic use is limited due to toxic effects (Bromberg et al., 2003; KanchanaGanga et al., 2013; Papież, 2013). In this context, the primary aim of this study was to gain insight into the possible mechanism(s) of the toxic effects of etoposide on testicular tissue and how these effects can be prevented.

In the current study, administration of etoposide induced lipid peroxidation, decreased the GSH content and the activities of SOD and CAT in rat testis. Malondialdehyde causes peroxidative damage of cellular lipid content (Berryman et al., 2004). Testis is a viable organ for oxidative stress because of its high content of polyunsaturated membrane lipids (Oguzturk et al., 2012). Reduced glutathione plays an important role in the maintenance of protein and lipid integrity, and provides major protection in oxidative injury (Ognjanovic et al., 2012).

Superoxide dismutase catalyzes the dismutation of superoxide anion radicals to hydrogen peroxides and in turn CAT degrades hydrogen peroxide into a molecule of oxygen and water (McCord, 2000).

Lowered activities of SOD and CAT, as noted in the current study, resulted in accumulation of these highly ROS that lead to detrimental effects in different tissues due to imbalance between ROS generation and antioxidant system. The present results were in agreement with previous studies, which reported the induction of oxidative stress and lipid peroxidation in anticancer drugs-treated animals (Kishore et al., 2010; Noori and Mahboob, 2010).

The current study showed that serum testosterone level has significantly decreased with etoposide treatment. This could be attributed to the impairment of Leydig cells or decreased numbers of luteinizing hormone (LH) receptors on Leydig cells (Silici et al., 2009). On the other hand, the weight of the testes is largely dependent on the mass of the differentiated spermatogenic cells, and the reduction in the weight of the testes may be due to the reduced tubule size, spermatogenic arrest and inhibition of steroid biosynthesis of Leydig cell (Chapin et al., 1997). In this context, the spermatogenic inhibition in etoposide-treated rats cannot only be the result of the reduced serum testosterone level. Besides hormonal alteration, the increased lipid peroxidation, decreased antioxidant enzymes and ATP depletion, that is mainly necessary for the flagellum movement of the sperm, may thus represent a key event linked to decreased spermatogenes (Beytur et al., 2012). Spermatozoa are 
liable to lipid peroxidation as they are rich in polyunsaturated fatty acids that are liable for lipid peroxidation by ROS (EI-Sweedy et al., 2007).

Etoposide increased pro-inflammatory markers (CRP and TNF- $\alpha$ ) in the current study. This may be explained as it activated the p38 mitogen-activated protein kinase in macrophages which plays a central role in the production of the pro-inflammatory cytokines, interleukins $1 \beta$ and 6 as well as TNF- $\alpha$ (Wood et al., 2006).

In alignment with the oxidative properties of etoposide, it resulted in significant decrease in ATP concentration and increase in mtDNA and nDNA damage in testicular tissue. Oxidative stress was shown to induce down-regulation of mitochondrial complex I and IV activity and decreased ATP concentrations in diabetic rats (Rastogi et al., 2008). The probability of loss of the reproductive capacity because of high sensitivity of gonads to cytostatic treatment explains the interest of clinicians to study the reproductive status of patients treated with etoposide (Ishikawa et al., 2004; Pectasides et al., 2004). In the testes, high concentration of topoisomerase II is present in spermatogonia (Hakovirta et al., 1999), and so, these cells are very sensitive to etoposide. In previous studies, it was showed that etoposide administration to pre-pubertal rats can cause germ cell apoptosis and testicular morphometric alterations, leading to Sertoli cell numerical alternation and serious seminiferous epithelium germ cell harm, leading to significant reduction in serum testosterone (Stumpp et al., 2004; Ortiz et al., 2009). In the light of these data, it is reasonable to consider that apoptosis was among causes of reduced spermatozoa production in the current study; however, further investigations are necessary to confirm this hypothesis.

Montelukast, a selective reversible LTD4 receptor antagonist, directly interferes with leukotriene production and their receptors (Kim et al., 2016; Teslariu et al., 2016). Treatment with montelukast could prevent lipid peroxidation in testes tissue. Only few studies clarified the effects of montelukast on oxidant/antioxidant status in testicular tissue. However, it was determined that montelukast reduced MDA level in rat testes after ischemic/reperfusion injury (Ozturk et al., 2010; Bentli et al., 2016). In harmony with the present results, montelukast prevented lipid peroxidation in liver and blood caused by carbon tetrachloride (Cuciureanu et al., 2009). In agreement, it was proved that montelukast can ameliorate lipid peroxidation and increase antioxidant properties in renal tissues after aminoglycosides administration (Kose et al., 2012). However, in contrast to the current results, testicular CAT activity and GSH level did not significantly changed upon administration of montelukast to cisplatin intoxicated rats, this may be explained with sensitivity of the rats and duration of drug treatment (Beytur et al., 2012).

Montelukast treatment reversed the decreased effect of etoposide on serum testosterone levels. To the best of our knowledge, there was no study about the effects of montelukast treatment on male fertility with etoposide treatment, however, it is thought that this effect of etoposide may occur through interference with $\mathrm{LH}$ receptor expression, impairment of the cholesterol mobilization to mitochondrial cytochrome $\mathrm{P} 450$, or reduction of the activity of this enzyme, thus interfering with the first steps in testosterone production (Silici et al., 2009).

Additionally, the current study showed that montelukast significantly increased sperm count, motility and viability in etoposide-treated rats. Previously, spermatological effects of montelukast did not examined with etoposide. Montelukast treatment might be beneficial due to its antioxidant, anti-inflammatory and antipoptotic properties and may be positively affect etoposide-induced infertility. 
In the histopathological evaluation, histological damage was decreased when montelukast was combined with etoposide. It was considered that the histopathological effects may attribute to the imbalance between oxidant and antioxidant statuses and/or increased inflammation and DNA damage in testes tissue induced by etoposide that may contribute also to male infertility by reducing sperm count. For this reason, a decrease in elevated oxidative stress in testes tissue with montelukast is very important in terms of infertility (Lirdi et al., 2008).

In relation to the evaluation of curcumin protective role, the current study revealed that curcumin attenuated the etoposide-induced MDA formation and the decreased testicular SOD activity. Additionally, curcumin treatment had a prominent protective effect in improving the testicular levels of GSH as well as CAT activities when compared to montelukast treated group. These results might possibly due to its intrinsic antioxidant properties (Palipoch et al., 2013). Similarly, curcumin protected against testicular oxidative damage induced by di-n-butylphthalate due to its intrinsic antioxidant properties (Farombi et al., 2007). The antioxidant mechanism of curcumin is due to its specific conjugated structure of two methoxylated phenols and an enol form of $\beta$-diketone, the structure showed a typical radical trapping ability as a chain breaking antioxidant (Masuda et al., 2001). Recently, A possible alternative explanation is that curcumin exerts its antioxidant and anti-inflammatory properties by a direct modulation of mitochondrial function (Claudia et al., 2017).

In the light of that, the potential effects of curcumin on spermatogenesis can be explained by the fact that it prevents cellular damage occurring as a result of oxidative stress in spermatogenic cells of seminiferous tubules and Leydig cells and thus relieve the reduction of testosterone level (Aly et al., 2009).

These effects, taken together, improved fertility and testicular performance, through controlling lipoperoxidation and which simultaneously affect sperm motility.

Germ cell apoptosis has been reported to play an important role in etoposideinduced testicular damage (Lizama et al., 2011). Curcumin may ameliorate testicular damage due to anti-apoptotic potential manifested by decrease in mtDNA and nDNA damage. The free radical scavenger activity and improving the antioxidant status of curcumin might justify this protective effect. Mitochondrial dysfunction is characterized by a decrease in energy production in the form of ATP. Mitochondrial dysfunction is caused by oxidative stress and represents an early event in aging and in the pathogenesis of age-related neuronal cell death and degenerative diseases (Eckert et al., 2013).

In the present study, curcumin had shown its anti-apoptotic property by significantly reducing DNA fragmentation when compared with etoposide-treated rats. Similarly, the anti-inflammatory effect of curcumin treatment was manifested by decreased serum CRP levels when compared to etoposide group. Additionally, a predominant significant decline in testicular levels of TNF- $\alpha$ when compared to montelukast treated group. These results can be explained by the ability of curcumin to modulate the expression of molecules involved in the inflammatory cascade and programmed cell death (Shehzad et al., 2013; Shishodia, 2013; Vecchi- Brumatti et al., 2014; Shanmugam et al., 2015).

\section{Conclusion}

In conclusion, the present study showed that montelukast and curcumin can reverse toxic effects of etoposide on the reproductive system that can be contributed due 
to anti-oxidant, anti-inflammatory and antiapoptotic potential. As protective agent, curcumin was found to be more effective in etoposide-induced testicular toxicity.

Further clinical and experimental studies are needed to determine the potential beneficial effects of these agents either with etoposide alone or with etoposide-based chemotherapy regimens before their clinical applications against testicular injury.

\section{REFERENCES}

Abdel-Raheem IT and Khedr NF (2014): Renoprotective effects of montelukast, a cysteinyl leukotriene receptor antagonist, against methotrexateinduced kidney damage in rats. Naunyn-Schmiedeberg's arch pharmacol. 387(4): 341-53.

Abercrombie M (1946): Estimation of nuclear population from microtome sections. Anat Rec ; 94: 238- 48.

Aebi H (1974): Catalase. In: Bergmeyer HU (ed) In methods of enzymatic analysis. Academic Press, NY, p 673-7.

Aly HA, Mansour AM, Abo-Salem OM, Abd-Ellah HF and Abdel-Naim AB (2009): Potential testicular toxicity of sodium nitrate in adult rats. Food Chem Tox ; 48: 572-8.

Bentli R, Ciftci O, Cetin A and Otlu A (2016): Anti-inflammatory Montelukast prevents toxic effects of 2,3, 7, 8-tetrachlorodibenzo-p-dioxin Oxidative stress, histological alterations in liver, and serum cytokine levels. Toxicol Indust Health. 32(5): 769-76.

Ben-Assayag E, Shenhar-Tsarfaty S, Bova I, Berliner S, Usher S, Peretz H, Shapira I, Bornstein NM (2009): Association of the -757TNC polymorphism in the CRP gene with circulating C-reactive protein levels and carotid atherosclerosis. Thrombosis Res; 124: 458-62.

Berryman AM, Maritim AC, Sanders RA and Watkins JB (2004): Influence of treatment of diabetic rats with combinations of pycnogenol, beta-carotene, and alpha-lipoic acid on parameters of oxidative stress. J Biochem Mol Toxicol ; 18: 345-52.

Beytur A, Ciftci O, Oguz F, Oguzturk H and Yilmaz F (2012): Montelukast attenuates side effects of cisplatin including testicular, spermatological, and hormonal damage in male rats. Cancer Chemother Pharmacol ; 69:207-13.

Bromberg KD, Burgin AB and Osheroff N (2003): A two-drug model for etoposide action against human topoisomerase II alpha. J Biol Chem; 278: 7406-12.

Chapin RE, Harris MW, Davis BJ, Ward SM, Wilson RE, Mauney MA, Lockhart AC, Smialowicz RJ, Moser VC, Burka LT, Collins BJ (1997): The effects of perinatal juvenile methoxychlor exposure on adult rat nervous, immune, and reproductive system function. Fundam Appl Toxicol ; 40:138-57.

Ciftci O, Aydin M, Ozdemir I and Vardi N (2012): Quercetin prevents 2,3,7,8tetrachlorodibenzo-p-dioxin-induced testicular damage in rats. Andrologia ; 44:164-73. 
Claudia L, Sara L, Matteo B, Liza VB, Elisa P, Erica V, Alberto T and Annalisa $M$ (2017): Curcumin Anti-Apoptotic Action in a Model of Intestinal Epithelial Inflammatory Damage. Nutrients ; 9 (6), 578-586.

Codelia VA, Cisterna M, Alvarez AR and Moreno RD (2010): P73 participates in male germ cells apoptosis induced by etoposide. Mol Hum Reprod ; 16: 734-42.

Cuciureanu M, Caruntu ID, Paduraru O, Satoica B, Jerca L, Crauciuc E and Nechifor M (2009): The protective effect of montelukast sodium on carbon tetrachloride induced hepatopathy in rat. Prostaglandins Other Lipid Mediat ; 88: 82-8.

Eckert GP, Lipka $U$ and Muller WE (2013): Omega-3 fatty acids in neurodegenerative diseases: focus on mitochondria. Prostaglandins Leukot Essent Fatty Acids ; 88: 105-14.

Ellman GL (1970): SH groups determination in biological fluids. Analy Biochem ; 46:237.

El-Sweedy M, Abdel-Hamid N and El-Moselhy M (2007): The role of a mixture of green tea, turmeric and chitosan in the treatment of obesity-related testicular disorders. J Appl Biomed; 5: 131-8.

Farombi EO, Abarikwu SO, Adedara IA and Oyeyemi MO (2007): Curcumin and kolaviron ameliorate di-n-butylphthalate-induced testicular damage in rats. Basic Clin Pharmacol Toxicol ; 100:43-8.

Francisca E, Freitas L, Cordeiro-Mori F, Sasso-Cerri E, Lucas R and Miraglia MS (2002): Alterations of spermatogenesis in etoposide-treated rats: a stereological study. Interciencia ; 27: 227-35.

Gray GM and Yardley HJ (1975): Mitochondria and nuclei of pig and human epidermis: isolation and lipid composition. J Invest Dermatol ; 64: 423-30.

Hakovirta H, Yan W, Kaleva M, Zhang F, Vänttinen K, Patricia L, Söder MM, Parvinen $M$ and Toppari J (1999): Function of stem cell factor as a survival factor of spermatogonia and localization of messenger ribonucleic acid in the rat seminiferous epithelium. Endocrinology ; 140: 1492-8.

Haraguchi C (1992): Effect of etoposide on mouse spermatogenesis. Jap J Fert \& Steril ; 37: 399- 407.

Icer M, Zengin Y, Gunduz E, Dursun R, Durgun HM (2016): Is montelukast as effective as $\mathrm{N}$-acetylcysteine in hepatic injury due to acetaminophen intoxication in rats? Exp Toxicol Pathol. 68(1): 55-59.

Ilbey YO, Ozbek E, Simsek A, Otunctemur A, Cekmen M and Somay A (2009): Potential chemoprotective effect of melatonin in cyclophosphamide- and cisplatin-induced testicular damage in rats. Fertil Steril ; 92:1124-32.

Ishikawa T, Kamidono $S$ and Fujisawa $M$ (2004): Fertility after high-dose chemotherapy for testicular cancer. Urology ; 63:137-40.

Joe B, Vijaykumar M and Lokesh BR (2004): Biological properties of curcumincellular and molecular mechanisms of action. Crit Rev Food Sci Nutr ; 44: 97-111. 
Kanchana-Ganga U, Kishori B and Sreenivasula Reddy P (2013): Cisplatin and/or etoposide induces oxidative stress in testicular, hepatic and kidney tissues in male albino mice. J Biol Earth Sci ; 3: B249-B54.

Kim BJ, Ryu SW and Song BJ (2006): JNK-and p38 kinase-mediated phosphorylation of Bax leads to its activation and mitochondrial translocation and to apoptosis of human hepatoma HepG2 cells. J Biol Chem ; 281: 21256-65.

Kim DW, Kim YH, Yousaf AM, Kim DS, Kwon TK (2016): Novel montelukast sodium-loaded stable oral suspension bioequivalent to the commercial granules in rats. Arch pharm res. 39(4): 539-46.

Kishore Reddy YV, Sreenivasula Reddy P, Shivalingam MR, Suvarchala Devi B, Pravallika G and Naga Anusha D (2010): Carboplatin-mediated changes in the activity levels of steroidogenic marker enzymes, serum hormones and testicular architecture in male rats. Drug Inven Today ; 2: 42-8.

Kose E, Beytur A, Dogan Z, Ekincioglu Z, Vardi N, Cinar K, Turkoz Y, Soysal H and Ekinci $N$ (2012): The effects of montelukast against amikacin induced acute renal damage. Eur Rev Med Pharmacol Sci ; 16: 503-11.

Lirdi LC, Stumpp T, Sasso-Cerri E and Miraglia M (2008): Amifostine protective effect on cisplatin-treated rat testis. Anat Rec (Hoboken) ; 29: 797-808.

Liu H, Jiang Y, Luo Y and Jiang WA (2006): Simple and rapid determination of ATP, ADP and AMP concentrations in pericarp tissue of litchi fruit by high performance liquid chromatography. Food Technol Biotechnol ; 44:531-4.

Lizama C, Ludwig A and Moreno RD (2011): Etoposide induces apoprosis and upregulation of TACE/ADAM17 and ADAM10 in an in vitro male germ cell line model. Biochim Biophys Acta ; 18:120-8.

Maestroni GJ, Covacci V and Conti A (1994): Hematopoietic rescue via T-celldependent, endogenous granulocyte-macrophage colony-stimulating factor induced by the pineal neurohormone melatonin in tumor-bearing mice. Cancer Res ; 54(9):2429-32.

Marcon L, Hales BF and Robaire B (2008): Reversibility of the effects of subchronic exposure to the cancer chemotherapeutics bleomycin, etoposide, and cisplatin on spermatogenesis, fertility, and progeny outcome in the male rat. J Androl ; 29: 408-17.

Marklund SL (1992): Regulation by cytokines of extracellular superoxide dismutase and other superoxide dismutase isoenzymes in fibroblasts. J Bio Chem ; 267: 6696-701.

Masuda T, Maekawa T, Hidaka K, Bando H, Takeda $Y$ and Yamaguchi $H$ (2001): Chemical studies on antioxidant mechanisms of curcumin: analysis of oxidative coupling products from curcumin and linoleate. J Agric Food Chem ; 49: 2539-47.

McCord JM (2000): The evolution of free radicals and oxidative stress. Am J Med ; 108: 652-9.

Meresse F, Dechaux E, Monneret $\mathbf{C}$ and Bertounesque $\mathbf{E}$ (2004): Etoposide: discovery and medicinal chemistry. Curr Med Chem; 11(18): 2443-66. 
Mizutani A, Okajima K, Uchiba M, Isobe H, Harada N, Mizutani S and Noguchi T (2003): Antithrombin reduces ischemia/reperfusion-induced renal injury in rats by inhibiting leukocyte activation through promotion of prostacyclin production. Blood ; 101: 3029-36.

Muthuraman A and Sood S (2010): Antisecretory, antioxidative and antiapoptotic effects of montelukast on pyloric ligation and water immersion stress induced peptic ulcer in rat. Prostaglandins Leukot Essent Fat Acids ; 83:5560 .

Nakahira K, Haspel JA, Rathinam VA, Lee S, Dolinay T, Lam HC, Englert JA, Rabinovitch M,Cernadas M, Kim HP, Fitzgerald KA, Ryter SW and Choi AM (2011): Autophagy proteins regulate innate immune responses by inhibiting the release of mitochondrial DNA mediated by the NALP3 inflammasome. Nature Immunology 12, 222-230.

Noori S and Mahboob T (2010): Antioxidant effect of carnosine pretreatment on cisplatin-induced renal oxidative stress in rats. Ind J Clin Biochem ; 25: 8691.

Ognjanovic BI, Djordjevic NZ, Matic MM, Obradović JM, Mladenović JM, Štajn AS and Saičić ZS (2012): Lipid peroxidative damage on cisplatin exposure and alterations in antioxidant defense system in rat kidneys: a possible protective effect of selenium. Int J Mol Sci ; 13: 1790-1803.

Oguzturk H, Ciftci O, Aydin M, Timurkaan N, Beytur A and Yilmaz F (2012): Ameliorative effects of curcumin against acute cadmium toxicity on male $\mathrm{r}$ eproductive system in rats. Andrologia ; 44:243-9.

Ortiz RJ, Lizama C, Codelia VA and Moreno RD (2009): A molecular evaluation of germ cell death induced by etoposide in pubertal rat testes. Mol Hum Reprod ; 15:363-71.

Oyeyemi MO and Ubiogoro $O$ (2005): Spermiogram and morphological characteristics in testicular and epididymal spermatozoa of Large White Boar in Nigeria. Int J Morphol ; 23: 235-9.

Ozkan E, Yardimci S, Dulundu E, Topaloğlu U, Şehirli O, Ercan F, Öğünç AV and Şener G (2010): Protective potential of montelukast against hepatic ischemia/reperfusion injury in rats. J Surg Res ; 159:588-94.

Ozturk H, Ozturk H, Gideroglu K, Terzi H, Bugdayci G (2010): Montelukast protects against testes ischemia/reperfusion injury in rats. Can Urol Assos J ; 4: 174-9.

Palipoch S, Punsawad C, Chinnapun D and Suwannalert P (2013): Amelioration of Cisplatin-Induced Nephrotoxicity in Rats by Curcumin and $\alpha$ Tocopherol. Trop J Pharm Res ; 12: 973-9.

Pant N and Srivastava SP (2003): Testicular and spermatotoxic effect of quinaphos in rats. J Appl Toxicol ; 23: 271-4.

Papież MA (2013): The influence of curcumin and (-)-epicatechin on the genotoxicity and myelosuppression induced by etoposide in bone marrow cells of male rats. Drug Chem Toxicol ; 36:93-101. 
Pectasides D, Pectasides M, Farmakis D, Nikolaou M, Koumpou M, Kostopoulou V and Mylonakis N (2004): Testicular function in patients with testicular cancer treated with bleomycin-etoposide-carboplatin (BEC(90)) combination chemotherapy. Eur Urol ; 45:187-93.

Preuss H, Jarrel S, Scheckenobach R, Lieberman S and Anderson R (1998): Comparative effects of chromium, vanadium and Gymnema sylvestre on sugar-induced blood pressure elevations in SHR. J Am Coll of Nutr ; 17: 116-23.

Rastogi M, Ojha RP, Rajamanickam GV, Agrawal A, Aggarwal A and Dubey GP (2008): Curcuminoids modulates oxidative damage and mitochondrial dysfunction in diabetic rat brain. Free Radic Res 2008; 42: 999-1005.

Sambrook J, Maniatis T and Fritsch FF (2001): Molecular Cloning, A Laboratory Manual, 3rd ed. Cold Spring Harbor Laboratory Press, Cold Spring Harbor, NY.

Shanmugam MK, Rane G, Kanchi MM, Arfuso F, Chinnathambi A, Zayed ME, Alharbi SA, Tan BK, Kumar AP and Sethi G (2015): The multifaceted role of curcumin in cancer prevention and treatment. Molecules. 20:27282769.

Shehzad A, Lee J and Lee YS (2013): Curcumin in various cancers. Biofactors. ; 39:56-68.

Shishodia S (2013): Molecular mechanisms of curcumin action: Gene expression. Biofactors ; 39, 37-55.

Silici S, Ekmekcioglu O, Eraslan G and Demirtas A (2009): Antioxidative effect of royal jelly in cisplatin-induced testes damage. Urology ; 74:545-51.

Srivastava TG (2002): Orientation Training Course on Research Methodology in Reproductive Biomedicine. New Delhi: Department of Reproductive Biomedicine, National Institute of Health and Family Welfare. Enzyme linked immunosorbant assay for steroid hormones ; 55-8.

Stumpp T, Sasso-Cerri E. Freymüller E and Miraglia SM (2004): Apoptosis and testicular alterations in albino rats treated with etoposide during the prepubertal phase. Anat. Rec A Discov Mol Cell Evol Biol ; 279: 611-22.

Tapia E, Soto V, Ortiz-Vega KM, Zarco-Marquez G, Molina-Jijon E, CristobalGarc M, Santamar J, Garca-Nino WR, Correa F, Zazueta C and Pedraza-Chaverri' J (2012): Curcumin induces Nrf2 nuclear translocation and and prevents glomerular hypertension, hyper filtration, oxidant stress, and the decrease in antioxidant enzymes in 5/6 rats. Oxid Med Cell Longev; 2012: Article ID 269039, 14 pages.

Teslariu O, Agoroaei L, Mititelu-Tartau L, Zamfir C, Teslariu E (2016): Experimental researches regarding the montelukast influence in gentamicin induced acute nephrotoxicity. Farmacia. 64(2): 252-6.

Tirkey N, Kaur G, Vij G and Vhopra K (2005): Curcumin, a diferuloylmethane, attenuates Cyclosporine-induced renal dysfunction and oxidative stress in rat kidneys. BMC Pharmacol ; 5: 15. 
Vecchi- Brumatti L, Marcuzzi A, Tricarico PM, Zanin V, Girardelli M, Bianco AM (2014): Curcumin and inflammatory bowel disease: Potential and limits of innovative treatments. Molecules ;19, 21127-21153.

Vogler GA (2006): Anesthesia and analgesia. In: Suckow MA, Weisbroth SH, Franklin CL (Eds.), The Laboratory Rat. Elsevier Academic Press, New York, USA, p. 627-95.

Wells ME and Awa OA (1970): New technique for assessing acrosomal characteristics of spermatozoa. J Diary Sci ; 53: 227-32.

Wood LJ, Nail LM, Perrin NA, Elsea CR, Fischer A and Druker BJ (2006): The cancer chemotherapy drug etoposide (VP-16) induces proinflammatory Cytokine production and sickness behavior-like symptoms in a mouse model of Cancer chemotherapy-related symptoms. Biol Res Nurs ; 8: 15769.

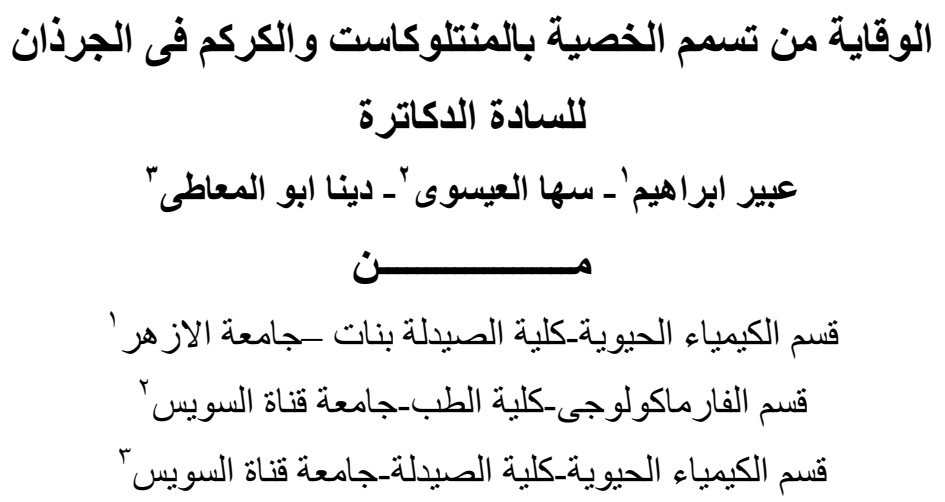

يعد نجاح الايتوبوزيد فى علاج سرطان الخصية محدود نظرا لاثاره الجانبية على الجهاز التناسلى.

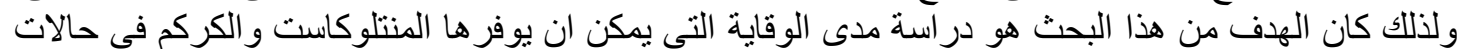

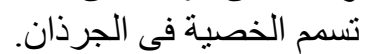

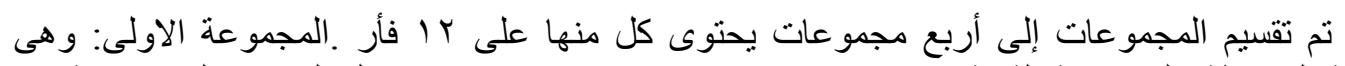

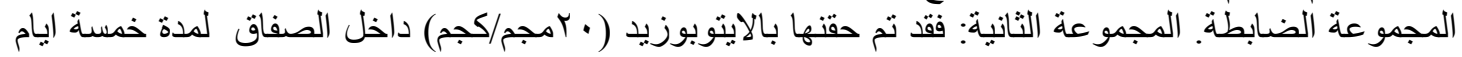

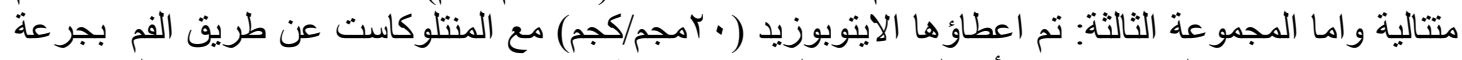

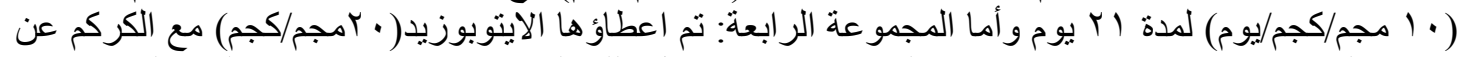

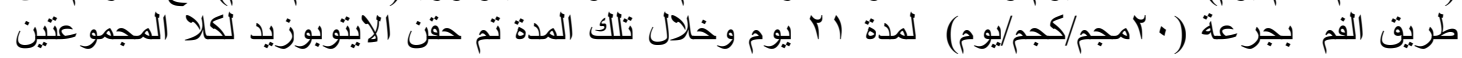

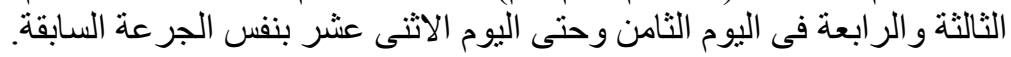

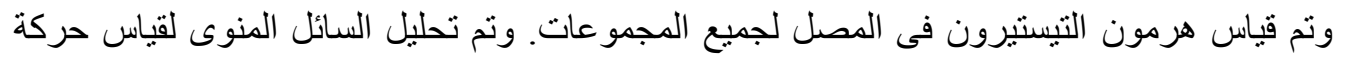

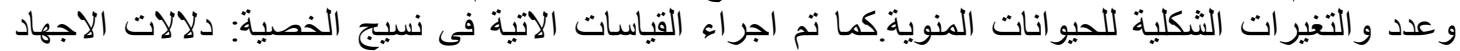

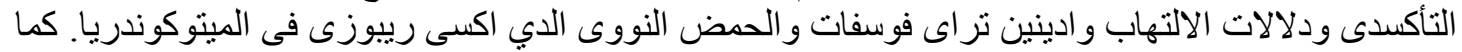
تم اجر اء بعض ودلالات القياسات الهيستو باتولوانين تراية في نسيج الخصية.

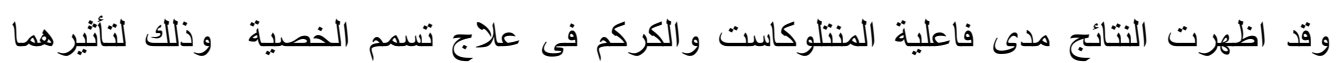

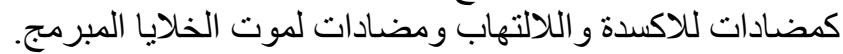

